\title{
The EDTA effect on phytoextraction of single and combined metals-contaminated soils using rainbow pink (Dianthus chinensis)
}

\author{
Hung-Yu Lai, Zueng-Sang Chen * \\ Graduate Institute of Agricultural Chemistry, National Taiwan University, Taipei 106-17, Taiwan
}

Received 17 November 2004; received in revised form 30 December 2004; accepted 14 January 2005

Available online 11 February 2005

\begin{abstract}
Rainbow pink (Dianthus chinensis), a potential phytoextraction plant, can accumulate high concentrations of Cd from metal-contaminated soils. The soils used in this study were artificially added with different metals including (1) $\mathrm{CK}$ : original soil, (2) Cd-treated soil: $10 \mathrm{mg} \mathrm{Cd} \mathrm{kg}^{-1}$, (3) $\mathrm{Zn}$-treated soil: $100 \mathrm{mg} \mathrm{Zn} \mathrm{kg}{ }^{-1}$, (4) $\mathrm{Pb}$-treated soil: $1000 \mathrm{mg} \mathrm{Pb} \mathrm{kg}{ }^{-1}$, (5) Cd-Zn-treated soil: $10 \mathrm{mg} \mathrm{Cd} \mathrm{kg}^{-1}$ and $100 \mathrm{mg} \mathrm{Zn} \mathrm{kg}^{-1}$, (6) Cd-Pb-treated soil: $10 \mathrm{mg} \mathrm{Cd} \mathrm{kg}$ and $1000 \mathrm{mg} \mathrm{Pb} \mathrm{kg}^{-1}$, (7) $\mathrm{Zn}-\mathrm{Pb}$-treated soil: $100 \mathrm{mg} \mathrm{Zn} \mathrm{kg}^{-1}$ and $1000 \mathrm{mg} \mathrm{Pb} \mathrm{kg}^{-1}$, and (8) $\mathrm{Cd}-\mathrm{Zn}-\mathrm{Pb}$-treated soil: $10 \mathrm{mg} \mathrm{Cd} \mathrm{kg}^{-1}, 100 \mathrm{mg} \mathrm{Zn} \mathrm{kg}^{-1}$, and $1000 \mathrm{mg} \mathrm{Pb} \mathrm{kg}^{-1}$. Three concentrations of 2Na-EDTA solutions (0 (control), 2, and $5 \mathrm{mmol} \mathrm{kg}$ soil) were added to the different metals-treated soils to study the influence of applied EDTA on single and combined metals-contaminated soils phytoextraction using rainbow pink. The results showed that the $\mathrm{Cd}$, $\mathrm{Zn}, \mathrm{Pb}, \mathrm{Fe}$, or $\mathrm{Mn}$ concentrations in different metals-treated soil solutions significantly increased after applying $5 \mathrm{mmol}$ EDTA $\mathrm{kg}^{-1}(p<0.05)$. The metal concentrations in different metals-treated soils extracted by deionized water also significantly increased after applying $5 \mathrm{mmol}$ EDTA kg$)^{-1}(p<0.05)$. Because of the high extraction capacity of both $0.005 \mathrm{M}$ DTPA (pH 5.3) and 0.05 M EDTA (pH 7.0), applying EDTA did not significantly increase the Cd, Zn, or $\mathrm{Pb}$ concentration in both extracts for most of the treatments. Applying EDTA solutions can significantly increase the $\mathrm{Cd}$ and $\mathrm{Pb}$ concentrations in the shoots of rainbow pink $(p<0.05)$. However, this was not statistically significant for $\mathrm{Zn}$ because of the low $\mathrm{Zn}$ concentration added into the contaminated soils. The results from this study indicate that applying 5 mmol EDTA $\mathrm{kg}^{-1}$ can significantly increase the $\mathrm{Cd}, \mathrm{Zn}$, or $\mathrm{Pb}$ concentrations both in the soil solution or extracted using deionized water in single or combined metals-contaminated soils, thus increasing the accumulated metals concentrations in rainbow pink shoots. The proposed method worked especially well for $\mathrm{Pb}(p<0.05)$. The application of 2 mmol EDTA kg-1 might too low to enhance the phytoextraction effect when used in silty clay soils.
\end{abstract}

(C) 2005 Elsevier Ltd. All rights reserved.

Keywords: EDTA; Rainbow pink; Phytoextraction; Cd; Zn; $\mathrm{Pb}$

\footnotetext{
* Corresponding author. Tel.: +88622369 8349; fax: +8862 23924335.

E-mail address: soilchen@ccms.ntu.edu.tw (Z.-S. Chen).
}

\section{Introduction}

Phytoremediation is the use of plants to remediate organic, inorganic, or nuclear pollutants in contaminated sites. This method includes phytoextraction, 
phytostabilization, phytovolatilization, phytodegradation, and phytofiltration techniques (Salt et al., 1995; Chaney et al., 1997; Lombi et al., 1998; Wenzel et al., 1999; Rodrigues and Duarte, 2003). Of these techniques, phytoextraction accumulates heavy metals from contaminated soil in plant roots with subsequent transfer into the shoots. These plants are then harvested, incinerated and buried (Kumar et al., 1995; Chaney et al., 1997; Wenzel et al., 1999; Garbisu and Alkorta, 2001).

Over 400 hyperaccumulator plant species from all over the world can accumulate high concentrations of metals from contaminated sites (Baker et al., 2000). However, many of these plants have a low growth rate and very low biomass. Therefore much time is needed to remove contaminants from soils. Two strategies, one involving synthesized chelating agents and the other involving genetic engineering, are being developed to increase the phytoextraction effect. Synthesized chelating agents, such as EDTA (ethylenedinitrilotetraacetic acid), DTPA (diethylenetrinitrilopentaacetic acid), HEDTA (hydroxyethylenediaminetriacetic acid), CDTA (trans1,2-cyclohexylenedinitrilotetraacetic acid), and EGTA (ethylenebis(oxyethylenetrinitrilo)tetraacetic acid), were applied to metal-contaminated soil to increase the mobility and bioavailability of the metals in the soils, thereby increasing the amount of heavy metals accumulated in the upper parts of phytoextracting plants (Huang and Cunningham, 1996; Blaylock et al., 1997; Huang et al., 1997; Ebbs and Kochian, 1998; Cooper et al., 1999; Lombi et al., 2001; Lai and Chen, 2004). These results revealed that adding synthetic chelating agents can increase both the solubility of the metal in the soil solution and the metal concentration in the plant shoots in single metal-contaminated soils. However, in soils contaminated with multiple metals, the application of synthetic chelating agents can reduce both the plant biomass and the total amount of metals removed because the high concentrations of other metals in the soil solution are toxic to the plant (Chen and Cutright, 2001; Lombi et al., 2001). Synthetic chelating agents at high concentrations can also be toxic to plants (Cooper et al., 1999). Applying synthetic chelating agents to soils contaminated by multiple metals represents another challenge for chemical phytoextraction enhancement by plants grown in contaminated sites.

Using commercial or garden plants to remove metals from contaminated soils is a popular and satisfactory strategy, because it returns the contaminated sites to their natural condition and generates economic value if appropriate flower species are cultivated. Chen and Lee (1997) reported that when rainbow pink was grown in a Cd-contaminated site in Northern Taiwan for five weeks, the $\mathrm{Cd}$ concentration in the plant shoots increased from 1.56 (under the control treatment) to $115 \mathrm{mg} \mathrm{kg}^{-1}$ (73.7-fold) and the total $\mathrm{Cd}$ uptake was about $100 \mathrm{~g} \mathrm{ha}^{-1} \mathrm{y}^{-1}$. These findings show that this plant can accumulate high concentrations of Cd. Moreover, the accumulated $\mathrm{Cd}$ concentration can reach a threshold (100 mg Cd kg-1) of a Cd hyperaccumulator (Baker et al., 2000). Lai and Chen (2004) reported that applying 5 or 10 mmol EDTA $\mathrm{kg}^{-1}$ can significantly increase the $\mathrm{Cd}, \mathrm{Zn}$, and $\mathrm{Pb}$ concentration in the soil solution and significantly increase the accumulated $\mathrm{Pb}$ concentration in the shoots of rainbow pink when growing in $\mathrm{Cd}, \mathrm{Zn}$, and $\mathrm{Pb}$-contaminated soils. However, the $\mathrm{Cd}$ and $\mathrm{Zn}$ concentration in rainbow pink shoots did not increase significantly after applying EDTA solutions. This result revealed that the EDTA effect on phytoextraction by rainbow pink is not identical in single and combined metal-contaminated soils.

The objectives of this study are (1) to identify the EDTA effect on the heavy metal concentrations in the soil solution or different soil extracts when rainbow pink is grown in artificial single or combined metal-treated soils, and (2) to evaluate the EDTA effect on the phytoextraction of single and combined metal-treated soils using rainbow pink.

\section{Materials and methods}

\subsection{Soil characteristics}

A rural soil contaminated by discharged wastewater from manufacturing plants and artificially added metals was used in pot experiments. The soil $\mathrm{pH}$ value was determined using glass electrodes in a soil to water ratio of 1:1 (McLean, 1982). The soil particle size distribution was analyzed using the pipette method (Gee and Bauder, 1986). The organic carbon content was determined using the Walkley-Black wet combustion method (Nelson and Sommers, 1982). The cation exchange capacity (CEC) was determined using the ammonium acetate method. The total $\mathrm{Cd}, \mathrm{Zn}$, and $\mathrm{Pb}$ concentrations in contaminated soils were digested by aqua regia and determined using atomic absorption spectrometer (Hitachi 180-30 type) (EPA/ROC, 2002).

\subsection{Soil pre-treatment}

The soil used in this study was collected from a Cdcontaminated site in Northern Taiwan. The surface soil $(0-20 \mathrm{~cm})$ of the contaminated site was sampled, airdried, and ground to pass through a $2 \mathrm{~mm}$ sieve. The soil was stored in large plastic bottles for laboratory analysis and pot experiments. Three single or combination solutions, $\mathrm{Cd}\left(\mathrm{NO}_{3}\right)_{2} \cdot 4 \mathrm{H}_{2} \mathrm{O}, \mathrm{ZnO}$, or $\mathrm{Pb}\left(\mathrm{NO}_{3}\right)_{2}$, were added to the air-dried soil to control the total concentrations (as individual element concentration) of three metals used in the following treatments: (1) CK: original soil, (2) Cd-treated soil: $10 \mathrm{mg} \mathrm{Cd} \mathrm{kg}^{-1}$, (3) Zn-treated soil: $100 \mathrm{mg} \mathrm{Zn} \mathrm{kg}^{-1}$, (4) Pb-treated soils: $1000 \mathrm{mg} \mathrm{Pb} \mathrm{kg}^{-1}$, 
(5) $\mathrm{Cd}-\mathrm{Zn}$-treated soil: combined polluted using $10 \mathrm{mg} \mathrm{Cd} \mathrm{kg}{ }^{-1}$ and $100 \mathrm{mg} \mathrm{Zn} \mathrm{kg}{ }^{-1}$, (6) Cd-Pb-treated soil: combined polluted using $10 \mathrm{mg} \mathrm{Cd}$ and 1000 $\mathrm{mg} \mathrm{Pb} \mathrm{kg}{ }^{-1}$, (7) $\mathrm{Zn}-\mathrm{Pb}$-treated soil: combined polluted using $100 \mathrm{mg} \mathrm{Zn} \mathrm{kg}^{-1}$ and $1000 \mathrm{mg} \mathrm{Pb} \mathrm{kg}^{-1}$, and (8) $\mathrm{Cd}-\mathrm{Zn}-\mathrm{Pb}$-treated soil: combined polluted using $10 \mathrm{mg} \mathrm{Cd} \mathrm{kg}^{-1}, 100 \mathrm{mg} \mathrm{Zn} \mathrm{kg}^{-1}$, and $1000 \mathrm{mg} \mathrm{Pb} \mathrm{kg}^{-1}$. The metal-treated soils were wetted for two weeks by adding deionized water to maintain a water content of $60 \%$ of the water-holding capacity. The soils were then dried at room temperature for approximately four weeks. The artificially contaminated soil was subjected to three cycles of wet and dry processes before pot experiments were conducted to enable the added heavy metals to reach a steady state (Blaylock et al., 1997).

\subsection{Pot experiments and laboratory analysis}

Each pot $(16 \mathrm{~cm}$ diameter and $19 \mathrm{~cm}$ height $)$ contained $3.0 \mathrm{~kg}$ (dry weight) of artificially metals-treated soils. Two rhizon soil moisture samplers (RSMS) were placed into each pot at a depth of about $10 \mathrm{~cm}$ below the soil surface. One rainbow pink seedling (Dianthus chinensis) was planted in each pot. The pot experiments were conducted in a phytotron using a RCBD (randomized complete block design) with a number of treatments and three replicates. The soil moisture content was maintained at $60 \%$ of the water-holding capacity, by weight with deionized water added every two days.

After growing for $21 \mathrm{~d}$, three $2 \mathrm{Na}$-EDTA solution concentrations ( 0 (control), 2, and $5 \mathrm{mmol} \mathrm{kg}^{-1}$ soil) were added to the different metal-treated soils. The growth conditions and observed toxicity symptoms displayed by the plants were also recorded. The rainbow pink shoots were harvested on the seventh day after the EDTA solution was first added to the pot. The harvested plants were rinsed with tap-water to remove soil adhered to the stem and leave surfaces and then ovendried at $60{ }^{\circ} \mathrm{C}$ for $72 \mathrm{~h}$, weighed, and ground to $0.5 \mathrm{~mm}$ for analysis. Then $0.2 \mathrm{~g}$ of the plants were digested using the $\mathrm{H}_{2} \mathrm{SO}_{4} / \mathrm{H}_{2} \mathrm{O}_{2}$ digestion method (Harmon and Lajtha, 1999). The digested solutions were filtered through Whatman No. 42 filter paper, and then diluted with deionized water to a volume of $50 \mathrm{ml}$ in a flask. The $\mathrm{Cd}, \mathrm{Zn}$, and $\mathrm{Pb}$ concentrations were determined using inductively coupled plasma optical emission spectrometer (ICP-OES) (Perkin Elmer 2000 DV).

Soil solutions were also collected directly using RSMS before adding EDTA solutions and at $7 \mathrm{~d}$ after adding EDTA solutions. The $\mathrm{Cd}, \mathrm{Zn}$, and $\mathrm{Pb}$ concentrations in the tested soil after harvesting were extracted using deionized water (Mench et al., 1994), $0.05 \mathrm{M}$ EDTA (pH 7.0) (Mench et al., 1994), and $0.005 \mathrm{M}$ DTPA (pH 5.3) (Lindsay and Norvell, 1978). The Cd, $\mathrm{Zn}$, and $\mathrm{Pb}$ concentrations in the soil solutions or in different extracts were determined using ICP-OES (Perkin
Elmer $2000 \mathrm{DV})$. To understand the concentration change in other elements after applying the EDTA solutions, the $\mathrm{Ca}, \mathrm{Mg}, \mathrm{Fe}$, and $\mathrm{Mn}$ concentrations in the soil solutions were determined using ICP-OES.

\subsection{Statistics}

The variance and significance of the differences among the element concentrations in the soil solutions, extracted using different agents, and in the plants were analyzed by ANOVA. Statistical significance was defined as $p=0.05$.

\section{Results and discussion}

\subsection{Soil characteristics}

Table 1 shows the physical and chemical characteristics of the studied soil. The studied soil texture was silty clay with a moderate cation exchange capacity of $13.9 \mathrm{cmol}_{(+)} \mathrm{kg}^{-1}$ soil. The original total metal concentrations in the contaminated soil, digested by aqua regia, were $2.58 \pm 0.08 \mathrm{mg} \mathrm{Cd} \mathrm{kg}^{-1}, \quad 80.0 \pm 5.32 \mathrm{mg} \mathrm{Zn} \mathrm{kg}^{-1}$, and $31.3 \pm 2.09 \mathrm{mg} \mathrm{Pb} \mathrm{kg}^{-1}$, respectively.

\subsection{The change in element concentration in the soil solutions after applying EDTA}

Adding $\mathrm{Cd}\left(\mathrm{NO}_{3}\right)_{2} \cdot 4 \mathrm{H}_{2} \mathrm{O}$ can increase the $\mathrm{Cd}$ concentration in a soil solution from not detectable (ND, below detection limit) in original soil (CK) to $0.14 \pm 0.07 \mathrm{mg}^{-1}$ in Cd-treated soil, $0.03 \pm 0.01 \mathrm{mg} \mathrm{l}^{-1}$ in $\mathrm{Cd}-\mathrm{Zn}$-treated soil, $1.34 \pm 0.47 \mathrm{mg}^{-1}$ in $\mathrm{Cd}-\mathrm{Pb}$-treated soil, and $1.38 \pm 0.43 \mathrm{mg}^{-1}$ in $\mathrm{Cd}-\mathrm{Zn}-\mathrm{Pb}$-treated soil, respectively. Adding $\mathrm{ZnO}$ or $\mathrm{Pb}\left(\mathrm{NO}_{3}\right)_{2}$ can also increase the $\mathrm{Zn}$ or $\mathrm{Pb}$ concentration in soil solutions (data not shown).

In the different heavy metals-treated soils, applying two concentrations of EDTA solutions ( 2 and $5 \mathrm{mmol}$ $\mathrm{kg}^{-1}$ ) can significantly increase the concentration of $\mathrm{Cd}, \mathrm{Zn}$, or $\mathrm{Pb}$ in soil solution $(p<0.05)$, except for applying 2 mmol EDTA kg-1 in both $\mathrm{Zn}$-treated soil and $\mathrm{Cd}-\mathrm{Pb}$-treated soil (Table 2). The soil used in this study was contaminated by $\mathrm{Cd}$ from wastewater discharged by manufacturing plants. The total $\mathrm{Cd}, \mathrm{Zn}$, and $\mathrm{Pb}$ concentration in the original contaminated soil analyzed by aqua regia was $2.58 \pm 0.08,80.0 \pm 5.32$, and $31.3 \pm 2.09 \mathrm{mg} \mathrm{kg}^{-1}$, respectively. In the original soil (CK) without artificially added metals, 2 or $5 \mathrm{mmol}$ applied EDTA $\mathrm{kg}^{-1}$ solutions could significantly increase the $\mathrm{Cd}, \mathrm{Zn}$, or $\mathrm{Pb}$ concentrations in the soil solutions $(p<0.05)$. However, the amount of increase was slight because of the low $\mathrm{Cd}, \mathrm{Zn}$, and $\mathrm{Pb}$ concentrations in the tested soil. Because the tested soil was a silty clay soil and the low EDTA application rate, no similar 
Table 1

The physical and chemical properties of the studied soil

\begin{tabular}{|c|c|c|c|c|c|c|}
\hline \multirow[t]{2}{*}{$\mathrm{pH}\left(\mathrm{H}_{2} \mathrm{O}\right)$} & \multirow[t]{2}{*}{$\mathrm{OC}\left(\mathrm{g} \mathrm{kg}^{-1}\right)^{\mathrm{a}}$} & \multirow[t]{2}{*}{ Texture } & \multirow{2}{*}{$\begin{array}{l}\mathrm{CEC} \\
\left(\mathrm{cmol}_{(+)} \mathrm{kg}^{-1} \text { soil }^{\mathrm{b}}\right.\end{array}$} & \multicolumn{3}{|c|}{ Metal concentration $\left(\mathrm{mg} \mathrm{kg}^{-1}\right)^{\mathrm{c}}$} \\
\hline & & & & $\overline{\mathrm{Cd}}$ & $\mathrm{Zn}$ & $\mathrm{Pb}$ \\
\hline 4.9 & 16.9 & Silty clay ${ }^{\mathrm{d}}$ & 13.9 & $2.58 \pm 0.08$ & $80.0 \pm 5.32$ & $31.3 \pm 2.09$ \\
\hline
\end{tabular}

Table 2

The change in element concentrations in the soil solutions before application and at the seventh day after applying 2 and $5 \mathrm{mmol} \mathrm{kg}{ }^{-1}$ EDTA solutions

\begin{tabular}{|c|c|c|c|c|c|c|c|c|}
\hline Treatment & $\begin{array}{l}\text { EDTA concentration } \\
\left(\mathrm{mmol} \mathrm{kg}{ }^{-1} \text { soil }\right)\end{array}$ & $\mathrm{Cd}$ & $\mathrm{Zn}$ & $\mathrm{Pb}$ & $\mathrm{Ca}$ & $\mathrm{Mg}$ & $\mathrm{Fe}$ & $\mathrm{Mn}$ \\
\hline \multirow[t]{3}{*}{$\mathrm{CK}$} & 0 & ns & ns & ns & $\mathrm{ns}$ & ns & ns & $\mathrm{ns}$ \\
\hline & 2 & $*$ & $*$ & ns & ns & ns & $* *$ & $* *$ \\
\hline & 5 & $* *$ & $* *$ & $*$ & $\mathrm{~ns}$ & ns & $* *$ & $*$ \\
\hline \multirow[t]{3}{*}{$\mathrm{Cd}$} & 0 & ns & ns & ns & $\mathrm{ns}$ & ns & ns & ns \\
\hline & 2 & $* *$ & $* * *$ & $* * *$ & $\mathrm{~ns}$ & ns & $* *$ & $* * *$ \\
\hline & 5 & $* * *$ & $* * *$ & $* * *$ & $\mathrm{~ns}$ & ns & $* * *$ & $*$ \\
\hline \multirow[t]{3}{*}{$\mathrm{Zn}$} & 0 & ns & ns & ns & $\mathrm{ns}$ & ns & ns & $\mathrm{ns}$ \\
\hline & 2 & ns & ns & ns & $\mathrm{ns}$ & ns & $*$ & $*$ \\
\hline & 5 & $* *$ & $* * *$ & $* * *$ & $\mathrm{~ns}$ & ns & $* * *$ & $*$ \\
\hline \multirow[t]{3}{*}{$\mathrm{Pb}$} & 0 & ns & ns & ns & $\mathrm{ns}$ & ns & ns & ns \\
\hline & 2 & ns & ns & $*$ & $\mathrm{~ns}$ & ns & ns & $\mathrm{ns}$ \\
\hline & 5 & ns & ns & $* *$ & $\mathrm{~ns}$ & ns & $*$ & $\mathrm{~ns}$ \\
\hline \multirow[t]{3}{*}{$\mathrm{Cd}+\mathrm{Zn}$} & 0 & ns & ns & ns & $\mathrm{ns}$ & ns & ns & ns \\
\hline & 2 & $* * *$ & $* * *$ & $* * *$ & $\mathrm{~ns}$ & ns & $* * *$ & ns \\
\hline & 5 & $* * *$ & $* * *$ & $* * *$ & $\mathrm{~ns}$ & ns & $* *$ & $* * *$ \\
\hline \multirow[t]{3}{*}{$\mathrm{Cd}+\mathrm{Pb}$} & 0 & ns & ns & ns & ns & ns & ns & ns \\
\hline & 2 & ns & ns & $*$ & $\mathrm{~ns}$ & ns & $* *$ & $\mathrm{~ns}$ \\
\hline & 5 & $*$ & $*$ & $* *$ & $\mathrm{~ns}$ & ns & $* * *$ & $\mathrm{~ns}$ \\
\hline \multirow[t]{3}{*}{$\mathrm{Zn}+\mathrm{Pb}$} & 0 & $*$ & ns & ns & ns & ns & ns & ns \\
\hline & 2 & $*$ & $* *$ & $*$ & $\mathrm{~ns}$ & ns & ns & $* *$ \\
\hline & 5 & $* * *$ & $* * *$ & $* * *$ & $\mathrm{~ns}$ & ns & $* * *$ & $* *$ \\
\hline \multirow[t]{3}{*}{$\mathrm{Cd}+\mathrm{Zn}+\mathrm{Pb}$} & 0 & ns & ns & ns & ns & ns & ns & ns \\
\hline & 2 & $*$ & $*$ & $* * *$ & $\mathrm{~ns}$ & ns & $*$ & $\mathrm{~ns}$ \\
\hline & 5 & $*$ & $* *$ & $* *$ & $*$ & ns & $* * *$ & $* * *$ \\
\hline
\end{tabular}

"ns": No significantly increased after applying EDTA solutions; $*: p<0.05, * *: p<0.01, * * *: p<0.001$.

change in the $\mathrm{Cd}, \mathrm{Zn}$, or $\mathrm{Pb}$ soil solution concentration occurred after applying 2 mmol EDTA $\mathrm{kg}^{-1}$ compared with $5 \mathrm{mmol}$ applied EDTA $\mathrm{kg}^{-1}$.

Except for the $\mathrm{Ca}$ concentration in $5 \mathrm{mmol}$ EDTA $\mathrm{kg}^{-1}$ treatment, no significant increase in the $\mathrm{Ca}$ and $\mathrm{Mg}$ soil solution concentration occurred after applying two EDTA treatments. However, most of the $\mathrm{Fe}$ and $\mathrm{Mn}$ soil solution concentrations increased significantly after applying 5 mmol EDTA kg ${ }^{-1}(p<0.05)$. Consistent with the $\mathrm{Cd}, \mathrm{Zn}$, and $\mathrm{Pb}$ soil solution concentration results after applying EDTA, no identical
$\mathrm{Fe}$ and Mn concentration results occurred after applying 2 mmol EDTA $\mathrm{kg}^{-1}$.

This result reveals that applying EDTA can increase the $\mathrm{Cd}, \mathrm{Zn}, \mathrm{Pb}, \mathrm{Fe}$, and $\mathrm{Mn}$ soil solution concentrations for metal-treated soils, but not for $\mathrm{Ca}$ and $\mathrm{Mg}$. Because of the low permeability of the tested soil compared with other studies (Huang et al., 1997; Chen and Cutright, 2001; Puschenreiter et al., 2001; Hammer and Keller, 2002) and the low EDTA application rate $\left(2 \mathrm{mmol} \mathrm{kg}^{-1}\right.$ soil) used in this study, the EDTA effect was statistically significant for only 5 mmol EDTA kg-1. 


\subsection{EDTA effect on the soil solution element concentration}

The $\mathrm{Cd}, \mathrm{Zn}$, and $\mathrm{Pb}$ concentration in the original soil increased significantly after applying $5 \mathrm{mmol}$ EDTA kg ${ }^{-1}(p<0.05)$ (Fig. 1). When considering the $\mathrm{Cd}$ soil solution concentration in different Cd-treated soils (i.e. $\mathrm{Cd}, \mathrm{Cd}-\mathrm{Zn}, \mathrm{Cd}-\mathrm{Pb}$, and $\mathrm{Cd}-\mathrm{Zn}-\mathrm{Pb}$-treated soil), applying 2 or 5 mmol EDTA $\mathrm{kg}^{-1}$ significantly increased the $\mathrm{Cd}$ concentration in the soil solution $(p<0.05)$, except for the $\mathrm{Cd}-\mathrm{Pb}$-treated soil (Fig. 1a). The Cd concentration in the soil solution of $\mathrm{Cd}-\mathrm{Pb}$-treated soil also increased after applying 2 or $5 \mathrm{mmol}$ EDTA kg ${ }^{-1}$, but was no significant difference. After applying 5 mmol EDTA kg-1 , the Cd concentration in the soil solution increased significantly from $0.14 \pm$ $0.07 \mathrm{mg} \mathrm{l}^{-1}$ to $5.90 \pm 1.14 \mathrm{mg} \mathrm{l}^{-1}$ (42-fold) in Cd-treated soil, and from $0.03 \pm 0.01 \mathrm{mg} \mathrm{l}^{-1}$ to $5.65 \pm 0.10 \mathrm{mg}^{-1}$ (188-fold) in Cd-Zn-treated soil, respectively $(p<0.05)$. Because of the low 2 mmol EDTA kg ${ }^{-1}$ application rate, no significant increase occurred in $\mathrm{CK}, \mathrm{Cd}-\mathrm{Pb}$, and $\mathrm{Cd}-$ $\mathrm{Zn}-\mathrm{Pb}$-treated soils after applying 2 mmol EDTA $\mathrm{kg}^{-1}$.

The $\mathrm{Zn}$ soil solution concentrations result after applying different EDTA solution concentrations was

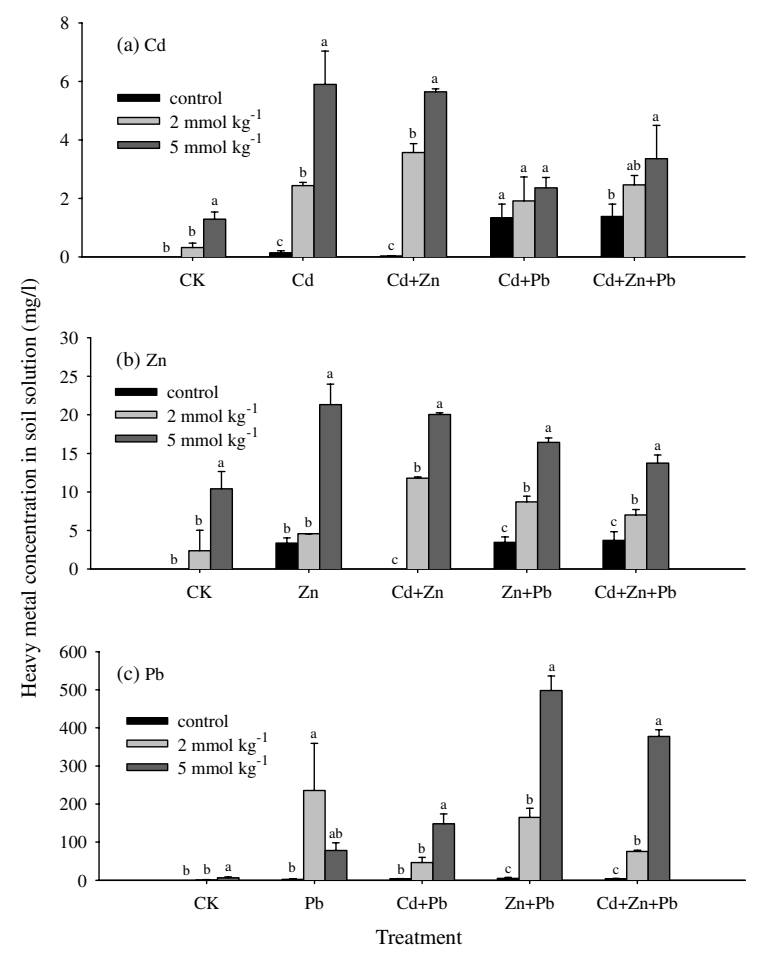

Fig. 1. The (a) Cd, (b) Zn, and (c) Pb concentrations in the soil solutions sampled at the seventh day after applying 2 and $5 \mathrm{mmol} \mathrm{kg}{ }^{-1}$ EDTA solutions. The probability level of significant difference is at $p=0.05$. Replicates $(n)=3$. similar to the Cd result (Fig. 1b). Applying $5 \mathrm{mmol}$ EDTA kg-1 could significantly increase the $\mathrm{Zn}$ concentration in the soil solutions of different $\mathrm{Zn}$-treated soils (i.e. $\mathrm{Zn}, \mathrm{Cd}-\mathrm{Zn}, \mathrm{Zn}-\mathrm{Pb}$, and $\mathrm{Cd}-\mathrm{Zn}-\mathrm{Pb}$-treated soil) $(p<0.001)$. The $\mathrm{Zn}$ concentrations in the soil solutions of different $\mathrm{Zn}$-treated soils were all below $4.0 \mathrm{mg}^{-1}$ before adding EDTA treatments. After treating with 5 mmol EDTA kg ${ }^{-1}$, the $\mathrm{Zn}$ concentration increased significantly to $13-22 \mathrm{mg} \mathrm{l}^{-1}(p<0.001)$. In soil treated artificially with $\mathrm{Zn}$, the $\mathrm{Zn}$ concentration in the soil solution increased significantly from $3.37 \pm 0.66 \mathrm{mg} \mathrm{l}^{-1}$ to $21.3 \pm 2.67 \mathrm{mg} \mathrm{l}^{-1}(6.3$-fold $)$ after applying $5 \mathrm{mmol}$ EDTA $\mathrm{kg}^{-1}$ treatment $(p<0.001)$. This was the highest concentration after applying 5 mmol EDTA kg-1 . Because of the low artificially added $\mathrm{Zn}$ concentration into the $\mathrm{Zn}$-treated soils, the $\mathrm{Zn}$ soil solution concentration after applying EDTA treatments was not as high as that reported in previous study (Lai and Chen, 2004).

Because of the low solubility of $\mathrm{Pb}$ in contaminated soil (Alloway, 1995), the $\mathrm{Pb}$ concentrations in the soil solutions of different $\mathrm{Pb}$-treated soils were low without adding EDTA (Fig. 1c). They were $2.49 \pm 1.38 \mathrm{mg}^{-1}$ in $\mathrm{Pb}$-treated soils, $3.87 \pm 0.88 \mathrm{mg}^{-1}$ in $\mathrm{Cd}-\mathrm{Pb}$-treated soil, $5.29 \pm 2.23 \mathrm{mg} \mathrm{l}^{-1}$ in $\mathrm{Zn}-\mathrm{Pb}$-treated soil, and $4.11 \pm$ $0.99 \mathrm{mg} \mathrm{l}^{-1}$ in $\mathrm{Cd}-\mathrm{Zn}-\mathrm{Pb}$-treated soil, respectively. Except when applying $2 \mathrm{mmol}$ EDTA kg-1 in artificially $\mathrm{Pb}$-treated soil, applying both EDTA solution concentrations significantly increased the $\mathrm{Pb}$ concentration in different $\mathrm{Pb}$-treated soil solutions (i.e. $\mathrm{Pb}, \mathrm{Cd}-\mathrm{Pb}, \mathrm{Zn}-$ $\mathrm{Pb}$, and $\mathrm{Cd}-\mathrm{Zn}-\mathrm{Pb}$-treated soil) $(p<0.05)$, especially for the $5 \mathrm{mmol}$ EDTA $\mathrm{kg}^{-1}$ (Fig. 1c). These results indicated that applying EDTA solutions can effectively to increase the metal concentration, especially for $\mathrm{Pb}$, in the soil solution. The differences in chelating effects between EDTA and metals are reflected by the formation constant $\left(\log K_{\mathrm{f}}=19.0\right) \quad$ Pb-ligand complexes, which exceeded those produced by Cd-ligand $\left(\log K_{\mathrm{f}}=17.4\right)$ and $\mathrm{Zn}$-ligand complexes $\left(\log K_{\mathrm{f}}=17.5\right)$. The maximum $\mathrm{Pb}$ soil solution concentration was $498 \pm 38.2 \mathrm{mg} \mathrm{l}^{-1}$ in the $\mathrm{Zn}-\mathrm{Pb}$-treated soil after applying the $5 \mathrm{mmol}$ EDTA kg ${ }^{-1}$ solution. After applying $2 \mathrm{mmol}$ EDTA kg${ }^{-1}$, the $\mathrm{Pb}$ soil solution concentration of artificially $\mathrm{Pb}$-treated soil was higher than that for the $5 \mathrm{mmol}$ EDTA $\mathrm{kg}^{-1}$ treatment. The $\mathrm{Pb}$ concentration was significantly increased from $2.49 \pm 1.38 \mathrm{mg} \mathrm{l}^{-1}$ (without applying EDTA solutions) to $236 \pm 123 \mathrm{mg} \mathrm{l}^{-1}(p<0.05)$. However, there was no significant difference between 2 and 5 mmol EDTA $\mathrm{kg}^{-1}$ in artificially $\mathrm{Pb}$-treated soil. This might be high variation of $\mathrm{Pb}$ concentration in the soil solutions after applying $2 \mathrm{mmol}$ EDTA $\mathrm{kg}^{-1}$ and some errors were occurred in the period of pot experiment.

The result in this study showed that applying $5 \mathrm{mmol}$ EDTA $\mathrm{kg}^{-1}$ efficiently increased the $\mathrm{Cd}, \mathrm{Zn}$, or $\mathrm{Pb}$ soil solution concentration in different metal-treated soils. This finding is consistent with those obtained following the EDTA treatments to contaminated soils in other 
studies (Blaylock et al., 1997; Huang et al., 1997; Wu et al., 1999; Luo et al., 2000; Chen and Cutright, 2001; Lombi et al., 2001; Hopgood et al., 2003). Because the soil used in this study was a silty clay soil, with lower permeability compared with sandy soil, the effects of applying $2 \mathrm{mmol} \mathrm{EDTA} \mathrm{kg}^{-1}$ on increasing the soil solution metal concentration were not identical. Lai and Chen (2004) reported that applying 5 and $10 \mathrm{mmol}$ EDTA $\mathrm{kg}^{-1}$ can significantly increase the soil solution metal concentration for the same soil used in this study. We thus propose that when applying EDTA to silty clay soil, more than 5 mmol EDTA $\mathrm{kg}^{-1}$ is necessary to efficiently and uniformly increase the soil solution metal concentration.

The $\mathrm{Ca}, \mathrm{Mg}, \mathrm{Fe}$, and $\mathrm{Mn}$ soil solution concentrations were also analyzed to investigate the changes in other element concentrations after applying EDTA solutions. The results showed that the $\mathrm{Ca}$ and $\mathrm{Mg}$ soil solution concentrations did not exhibit identical concentration increases after applying 2 or 5 mmol EDTA kg ${ }^{-1}$ (Fig. $2 \mathrm{a}$ and $\mathrm{b}$ ). However, the $\mathrm{Fe}$ and $\mathrm{Mn}$ soil solution concentrations increased significantly after applying both EDTA solutions $(p<0.05)$, especially for the $5 \mathrm{mmol}$ EDTA kg-1 treatment (Fig. 2c and d). Cooper et al. (1999) reported that applying high DTPA concentrations can significantly increase the Fe and Mn concentration in plants. However, the results were not significant for $\mathrm{Ca}$ and $\mathrm{Mg}$. Applying EDTA could significantly increase the $\mathrm{Fe}$ and $\mathrm{Mn}$ soil solution concentrations in this study, producing easier plant uptake. The result from this study was similar to the result by Cooper et al. (1999). The Fe soil solution concentrations without EDTA treatments were not detected in different metaltreated soils. Seven days after $2 \mathrm{mmol} \mathrm{kg}{ }^{-1}$ EDTA solutions were added to the soils, the $\mathrm{Fe}$ soil solution concentration increased significantly to the $70-210 \mathrm{mg} \mathrm{l}^{-1}$ $(p<0.05)$ level. Applying 5 mmol EDTA kg ${ }^{-1}$ was more efficient than that applying $2 \mathrm{mmol} \mathrm{EDTA} \mathrm{kg}^{-1}$, significantly increasing the $\mathrm{Fe}$ concentration to the $150-590 \mathrm{mg} \mathrm{l}^{-1}(p<0.05)$ level. The Mn soil solution concentration after applying EDTA showed the same increase as $\mathrm{Fe}$, even though some of the increases were not statistically significant.

\subsection{EDTA effect on the element extractable concentration}

\subsubsection{Deionized water}

After applying $5 \mathrm{mmol} \mathrm{EDTA} \mathrm{kg}^{-1}$, the deionized water extractable $\mathrm{Cd}, \mathrm{Zn}$, or $\mathrm{Pb}$ concentration of different metal-treated soils increased significantly $(p<0.05)$ (Fig. 3). The concentrations of metals extracted using deionized water were equal to the water soluble form in the contaminated soil (Gupta and Chen, 1975; Gatehouse et al., 1977; Mathur and Levesque, 1983; Jones et al., 1984; Miller et al., 1986), which were easily lea-
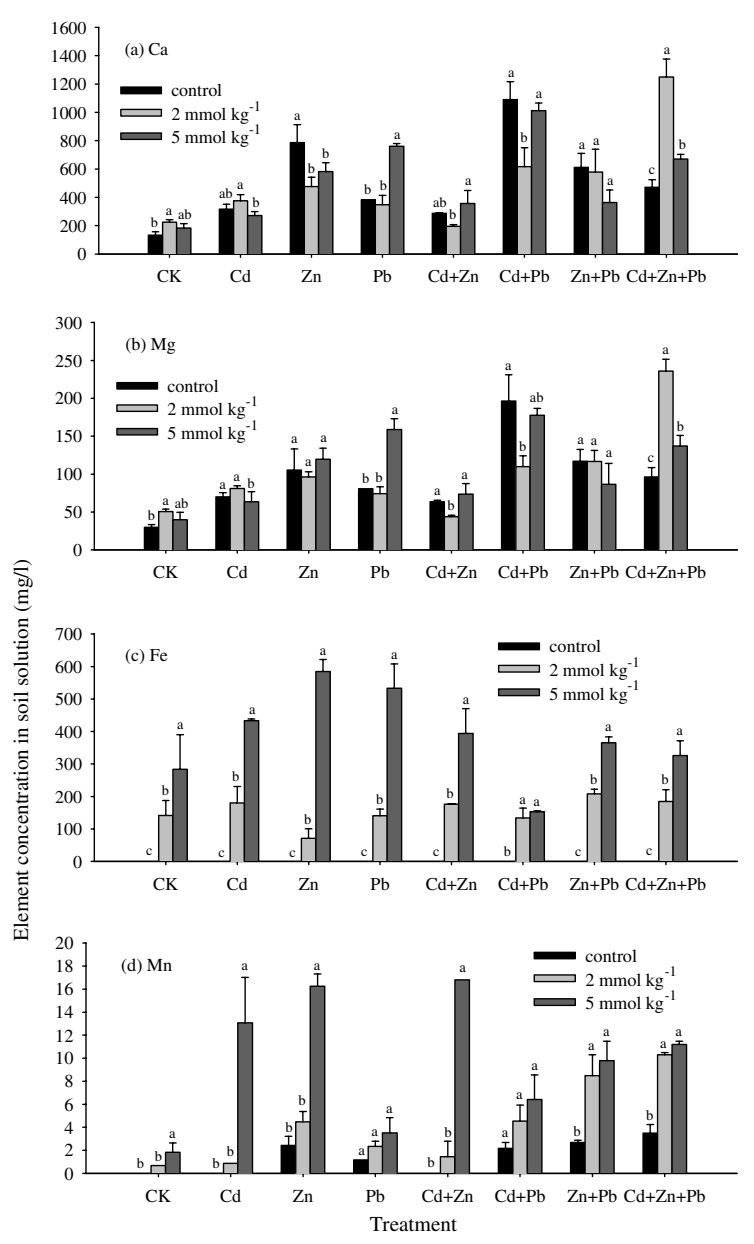

Fig. 2. The (a) $\mathrm{Ca}$, (b) $\mathrm{Mg}$, (c) $\mathrm{Fe}$, and (d) Mn concentrations in the soil solutions sampled at the seventh day after applying 2 and $5 \mathrm{mmol} \mathrm{kg}^{-1}$ EDTA solutions. The probability level of significant difference is at $p=0.05$. Replicates $(n)=3$.

ched into the groundwater along with rainfall. Because the soil used in this study was contaminated by heavy metals, applying 5 mmol EDTA kg-1 could significantly increase the deionized water extractable concentration of $\mathrm{Cd}, \mathrm{Zn}$, and $\mathrm{Pb}$ from the original contaminated soil. Applying 2 mmol EDTA kg-1 could not significantly to increase the amount water soluble metals in most treatments, except for the $\mathrm{Cd}$ concentration in Cd-treated soil and the $\mathrm{Zn}$ concentration in $\mathrm{Zn}$ and $\mathrm{Cd}-\mathrm{Zn}$-treated soil $(p<0.05)$. The reason is similar to that after applying 2 mmol EDTA kg-1, which was described in Sections 3.2 and 3.3. Among these three metals, applying $5 \mathrm{mmol}$ EDTA kg $^{-1}$ was the most efficient in increasing the $\mathrm{Pb}$ concentration in soil extracted using deionized water. In the different artificially $\mathrm{Pb}$-treated soils (i.e. $\mathrm{Pb}, \mathrm{Cd}-\mathrm{Pb}, \mathrm{Zn}-\mathrm{Pb}$, and $\mathrm{Cd}-\mathrm{Zn}-\mathrm{Pb}$-treated soil) without EDTA solution treatment, the deionized 


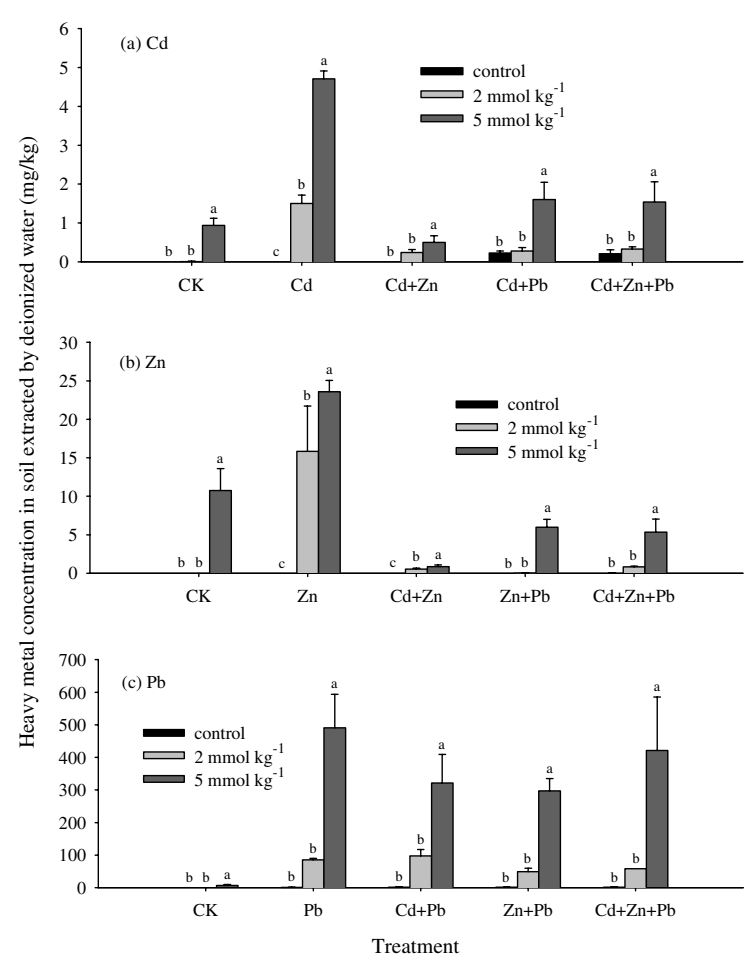

Fig. 3. The deionized water extractable concentrations for: (a) $\mathrm{Cd}$, (b) $\mathrm{Zn}$, and (c) $\mathrm{Pb}$ in soils sampled at the seventh day after applying 2 and $5 \mathrm{mmol} \mathrm{kg}^{-1}$ of EDTA solutions. The probability level of significant difference is at $p=0.05$. Replicates $(n)=3$.

water extractable $\mathrm{Pb}$ concentrations were all below $2 \mathrm{mg} \mathrm{kg}^{-1}$. After applying $5 \mathrm{mmol}$ EDTA kg${ }^{-1}$, the $\mathrm{Pb}$ concentration significantly increased $(p<0.05)$, and the concentration levels were from 300 to $500 \mathrm{mg} \mathrm{kg}^{-1}$ (Fig. 3c). These results show that applying EDTA into the different metal-treated soils could significantly increase the water soluble metal fraction in these soils $(p<0.05)$.

\subsubsection{DTPA and EDTA}

Fig. 4 shows the 0.005 M DTPA (pH 5.3) extractable concentrations for different metal-treated soils after applying 2 or 5 mmol EDTA $\mathrm{kg}^{-1}$ solutions. The results show that the concentrations extracted using DTPA were not significantly different for most metal-treated soils after applying EDTA treatments. This might because (1) The metals in artificially contaminated soils treated with different solutions existed for only a short period (about three months). This made the metals easier to extract than long-term contaminated soils. (2) The extracting agents (0.005 M DTPA) used in this study were strong enough to extract metals from the different metal-treated soils. The bioavailability of metals decreases with the amount of contamination time (Vig

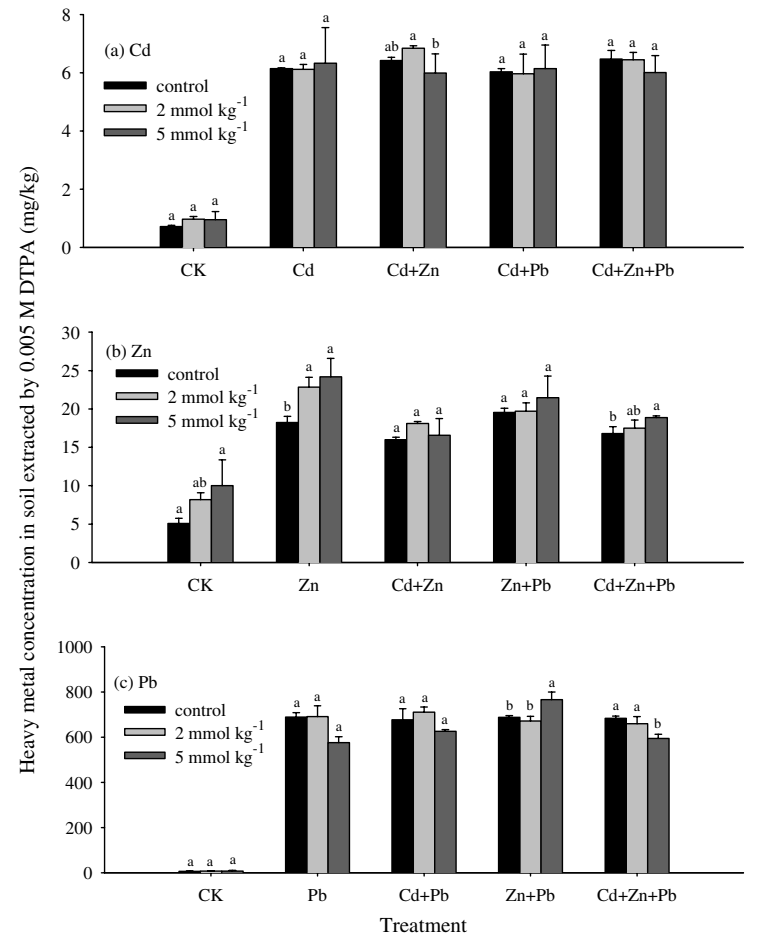

Fig. 4. The 0.005 M DTPA (pH 5.3) and extractable: (a) Cd, (b) $\mathrm{Zn}$, and (c) $\mathrm{Pb}$ soil concentrations sampled at the seventh day after applying 2 and $5 \mathrm{mmol} \mathrm{kg} \mathrm{k}^{-1}$ EDTA solutions. The probability level of significant difference is at $p=0.05$. Replicates $(n)=3$.

et al., 2003). Soil artificially contaminated by heavy metal will have high bioavailability compared with long-term contaminated soils. DTPA can extract higher amounts of metals in artificially contaminated soils than in long-term contaminated soils. Some authors indicated that $0.005 \mathrm{M}$ DTPA was able to extract heavy metals that were water soluble, exchangeable, organic matter bound, and fractions occluded in oxides (Stover et al., 1976; Sposito et al., 1982; Mathur and Levesque, 1983; Jones et al., 1984; Goldberg and Smith, 1984). We consider that most of the metals in the different metal-treated soils in this study existed in water soluble, exchangeable, or organic matter bound fractions. Because of the strong extracting capacity of $0.005 \mathrm{M}$ DTPA, which could extract most of the metal fractions in this tested soil, the $\mathrm{Cd}, \mathrm{Zn}$, and $\mathrm{Pb}$ concentrations in the extracts after adding different EDTA concentrations did not increase significantly for most of the metal-treated soils. Even through $0.005 \mathrm{M}$ DTPA is not suitable in assessing the EDTA effect on phytoextraction of heavy metals-contaminated soils by rainbow pink in this study. The DTPA extractable soil $\mathrm{Cd}, \mathrm{Cu}, \mathrm{Pb}$, and $\mathrm{Zn}$ concentration is useful to predict that concentration in plants (Parkpian et al., 2002). 


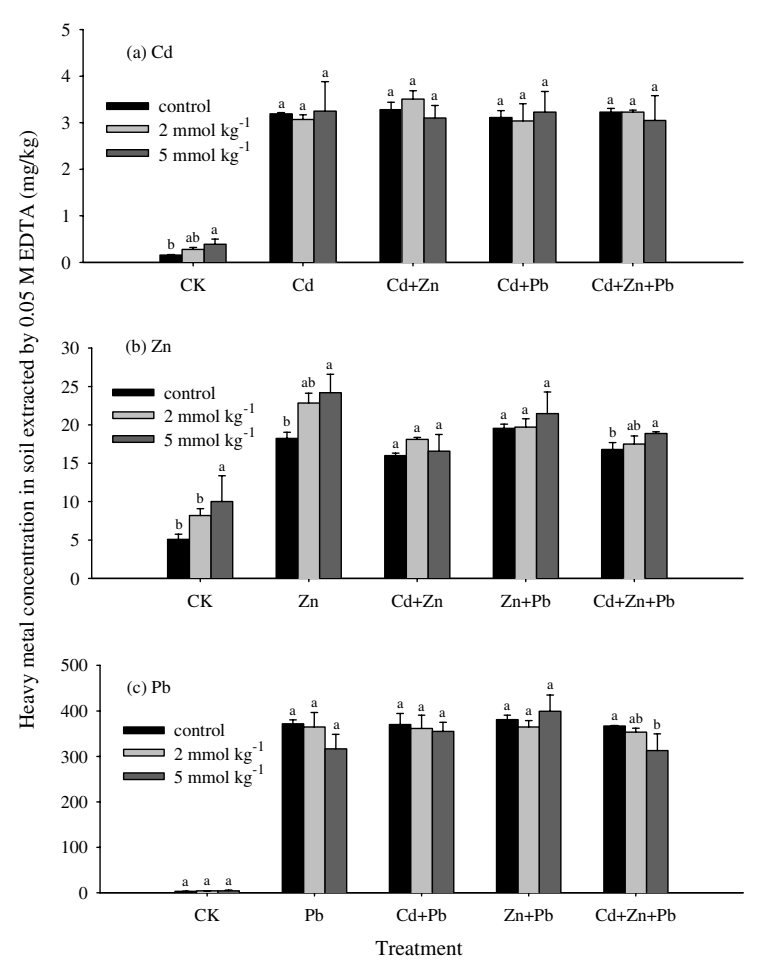

Fig. 5. The 0.05 M EDTA (pH 7.0) extractable: (a) Cd, (b) Zn, and (c) $\mathrm{Pb}$ soil concentrations sampled at the seventh day after applying 2 and $5 \mathrm{mmol} \mathrm{kg}{ }^{-1}$ EDTA solutions. The probability level of significant difference is at $p=0.05$. Replicates $(n)=3$.

The 0.05 M EDTA (pH 7.0) extractable Cd, Zn, and $\mathrm{Pb}$ concentration results were similar to the $0.005 \mathrm{M}$ DTPA (pH 5.3) results (Fig. 5). There was not significantly different for most of the EDTA extractable metals in the different metal-treated soils after adding different EDTA concentration treatments. Previous studies indicated that 0.05 M EDTA ( $\mathrm{pH}$ 7.0) can extract the same fractions with $0.005 \mathrm{M}$ DTPA (pH 5.3) (Jones et al., 1984; Miller et al., 1986). There were no significant increases in extract concentrations after applying 2 or $5 \mathrm{mmol} \mathrm{kg}{ }^{-1}$ EDTA solutions because of the strong extracting capacity of $0.05 \mathrm{M}$ EDTA.

\subsection{EDTA effect on $\mathrm{Cd}, \mathrm{Zn}$, and Pb uptake by rainbow pink}

In the different artificial Cd-treated soils (i.e. Cd, $\mathrm{Cd}-$ $\mathrm{Zn}, \mathrm{Cd}-\mathrm{Pb}$, and $\mathrm{Cd}-\mathrm{Zn}-\mathrm{Pb}$-treated soil), applying both 2 and 5 mmol EDTA kg ${ }^{-1}$ significantly increased the $\mathrm{Cd}$ concentration in rainbow pink shoots $(p<0.05)$, except for the $\mathrm{Cd}-\mathrm{Pb}$-treated soil (Fig. 6a). The accumulated $\mathrm{Cd}$ concentrations in rainbow pink shoots when growing in $\mathrm{Cd}-\mathrm{Pb}$-treated soils were not statistically significant because of (1) the Cd concentrations in soil solutions were not significantly increased after applying 2 and

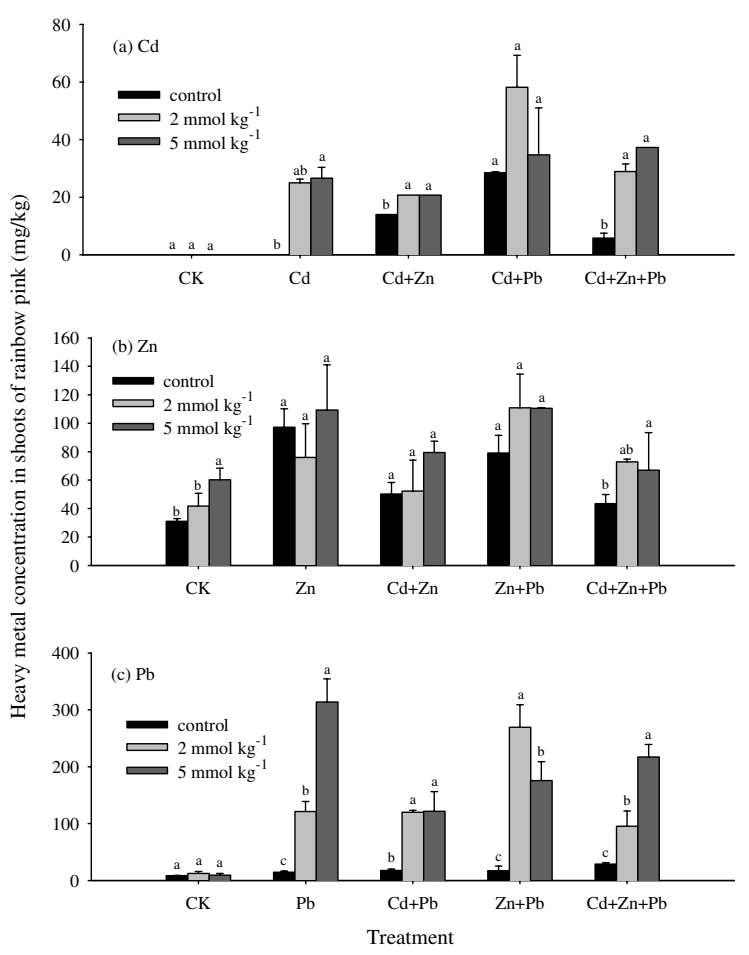

Fig. 6. The (a) $\mathrm{Cd}$, (b) $\mathrm{Zn}$, and (c) $\mathrm{Pb}$ concentrations in rainbow pink shoots harvested at the seventh day after applying 2 and $5 \mathrm{mmol} \mathrm{kg}{ }^{-1}$ EDTA solutions. Rainbow pink was grown for $21 \mathrm{~d}$ before applying the EDTA solutions. The probability level of significant difference is at $p=0.05$. Replicates $(n)=3$.

$5 \mathrm{mmol} \mathrm{kg} \mathrm{k}^{-1}$ EDTA solutions. (2) High variations in the $\mathrm{Cd}$ concentration in $\mathrm{Cd}-\mathrm{Pb}$-treated soils after applying 2 or $5 \mathrm{mmol} \mathrm{EDTA} \mathrm{kg}^{-1}$ solutions. Applying EDTA solutions significantly increased the $\mathrm{Cd}$ concentrations in both the soil solutions and $\mathrm{Cd}, \mathrm{Cd}-\mathrm{Zn}$, and $\mathrm{Cd}-\mathrm{Zn}-$ $\mathrm{Pb}$-treated soil $(p<0.05)$ extracted using deionized water. The accumulated $\mathrm{Cd}$ concentration in the rainbow pink shoots was thus significantly increased $(p<0.05)$. This result is similar to that reported by Lai and Chen (2004).

Although both the $\mathrm{Zn}$ concentration in soil solutions and deionized water extractable concentrations significantly increased after applying both EDTA solution concentrations $(p<0.05)$, the $\mathrm{Zn}$ concentrations in rainbow pink shoots were not significantly increased except for the $\mathrm{Cd}-\mathrm{Zn}-\mathrm{Pb}$-treated soil $(p<0.05)$ (Fig. 6b). The $\mathrm{Zn}$ concentrations levels in rainbow pink shoots were from 50 to $110 \mathrm{mg} \mathrm{kg}^{-1}$ in different $\mathrm{Zn}$-treated soils. Zinc is an essential element in maintaining plant growth. The mean content in these plants was from 1.2 to $73 \mathrm{mg} \mathrm{kg}^{-1}$ (Kabata-Pendias and Pendias, 2001). We considered that because of the low $\mathrm{Zn}$ concentration added into the different artificial metal-treated soils (0.05 M EDTA and 0.005 M DTPA extracted Zn were 
all below $30 \mathrm{mg} \mathrm{kg}^{-1}$ ), the $\mathrm{Zn}$ concentration in these shoots was sufficient for rainbow pink growth. Although the $\mathrm{Zn}$ concentration in both the soil solution and deionized water extracted increased significantly after applying EDTA solutions $(p<0.05)$, the $\mathrm{Zn}$ concentration in rainbow pink shoots was not significantly affected by the EDTA solution application when growing in different metal-treated soils. Some interactions may also contribute to the result described above. The synergism or antagonism effect among these metals is illustrated in this result.

When growing in the different metals-treated soils without added EDTA solutions, all accumulated $\mathrm{Pb}$ concentrations in rainbow pink shoots were below $30 \mathrm{mg} \mathrm{kg}^{-1}$ (Fig. 6c). This pattern is illustrated by the low $\mathrm{Pb}$ concentration in both the soil solution $\left(<6 \mathrm{mg}^{-1}\right)$ (Fig. 1c) and deionized water extracted samples $\left(<2 \mathrm{mg} \mathrm{kg}^{-1}\right)$ (Fig. 3c). After applying 2 and 5 mmol EDTA kg-1, the $\mathrm{Pb}$ concentration in rainbow pink shoots was increased significantly $(p<0.05)$.

Among the three metals, EDTA was most efficient in increasing the $\mathrm{Pb}$ concentration in rainbow pink shoots. This result is similar to that from other studies when EDTA was applied to metal-contaminated soil (Blaylock et al., 1997; Lai and Chen, 2004).

\section{Conclusion}

EDTA is considered a chelating agent that promotes the solubility of metals in contaminated sites, especially for $\mathrm{Pb}$. The EDTA solution application can significantly increase the metal concentrations in both soil solutions and deionized water extracted single or combined metal-contaminated soils $(p<0.05)$. Applying EDTA solution at a high concentration $\left(5 \mathrm{mmol} \mathrm{kg}^{-1}\right)$ increases the metal concentration in the soil solution or deionized water extracted concentration greater than that obtained using EDTA at a lower concentration $\left(2 \mathrm{mmol} \mathrm{kg}^{-1}\right)$. However, EDTA solutions may contribute to groundwater pollution. Both extracting agents, $0.005 \mathrm{M}$ DTPA (pH 5.3) and 0.05 M EDTA (pH 7.0), used in this study were too strong to identify the EDTA effect on the phytoextraction of single or combined metal-treated soils. Further study should avoid using these two extraction methods, especially when the metals in the contaminated soil are produced artificial addition or only contaminated for short period of time.

Adding EDTA solutions can efficiently and significantly increase the $\mathrm{Cd}$ and $\mathrm{Pb}$ concentrations in rainbow pink shoots for most single and combined metal-treated soils $(p<0.05)$, especially for $\mathrm{Pb}$. However, there was no uniform result for $\mathrm{Zn}$ because of the low $\mathrm{Zn}$ concentration added into the different metal-treated soils or the accumulated $\mathrm{Zn}$ in the shoots was sufficient rainbow pink growth. Some interactions among these three met- als might also exist in combined metal-treated soils and affect the accumulated metal concentrations in rainbow pink shoots. This will discussed further in a future article.

\section{Acknowledgment}

The authors would like to thank the National Science Council of the Republic of China for financially supporting this research under contract no. NSC91-2621B-002-003.

\section{References}

Alloway, B.J., 1995. Heavy Metals in Soils. Blackie Academic and Professional, Glasgow, UK.

Baker, A.J.M., McGrath, S.P., Reeves, R.D., Smith, J.A.C., 2000. Metal hyperaccumulator plants: a review of the ecology and physiology of a biological resource for phytoremediation of metal-polluted soils. In: Terry, N., Bañuelos, G. (Eds.), Phytoremediation of Contaminated Soil and Water. CRC Press LLC, USA, pp. 85-107.

Blaylock, M.J., Salt, D.E., Dushenkov, S., Zakharova, O., Gussman, C., Kapulnik, Y., Ensley, B.D., Raskin, I., 1997. Enhanced accumulation of $\mathrm{Pb}$ in Indian mustard by soilapplied chelating agents. Environ. Sci. Technol. 31, 860865.

Chaney, R.L., Malik, M., Li, Y.M., Brown, S.L., Brewer, E.P., Angle, J.S., Baker, A.J.M., 1997. Phytoremediation of soil metals. Environ. Biotechnol. 8, 279-284.

Chen, H., Cutright, T., 2001. EDTA and HEDTA effects on $\mathrm{Cd}, \mathrm{Cr}$, and $\mathrm{Ni}$ uptake by Helianthus annuus. Chemosphere $45,21-28$.

Chen, Z.S., Lee, D.Y., 1997. Evaluation of remediation techniques on two cadmium-polluted soils in Taiwan. In: Iskandar, I.K., Adriano, D.C. (Eds.), Remediation of Soils Contaminated with Metals. Science Reviews, Northwood, UK, pp. 209-223.

Cooper, E.M., Sims, J.T., Cunningham, S.D., Huang, J.W., Berti, W.R., 1999. Chelate-assisted phytoextraction of lead from contaminated soil. J. Environ. Qual. 28, 1709-1719.

Ebbs, S.D., Kochian, L.V., 1998. Phytoextraction of zinc by oat (Avena sativa), barley (Hordeum vulgare), and Indian mustard (Brassica juncea). Environ. Sci. Technol. 32, 802806.

EPA/ROC, 2002. The digestion methods of heavy metal in soils by aqua regia. Method code no: NIEA S321.62C. Environmental Protection Administration of Taiwan ROC. Taipei, Taiwan.

Garbisu, C., Alkorta, I., 2001. Phytoextraction: a cost-effective plant-based technology for the removal of metals from the environment. Biores. Technol. 77, 229-236.

Gatehouse, S., Russell, D.W., Van Moort, J.C., 1977. Sequential soil analysis in exploration geochemistry. J. Geochem. Explor. 8, 483-494.

Gee, G.W., Bauder, J.W., 1986. Particle-size analysis. In: Klute, A. et al. (Eds.), Methods of Soil Analysis. Part 1. Physical 
and Mineralogical Method. Second edition. Madison, WI, USA, Agronomy Monograph 9, pp. 383-412.

Goldberg, S.P., Smith, K.A., 1984. Soil manganese: $E$ values, distribution of manganese-54 mong soil fractions, and effects of drying. Soil Sci. Soc. Am. J. 48, 559-564.

Gupta, S.K., Chen, K.Y., 1975. Partitioning of trace metals in selective chemical fractions of near shore sediments. Environ. Lett. 10, 129-158.

Hammer, D., Keller, C., 2002. Changes in the rhizosphere of metal-accumulating plants evidenced by chemical extractants. J. Environ. Qual. 31, 1561-1569.

Harmon, M.E., Lajtha, K., 1999. Analysis of detritus and organic horizons for mineral and organic constitutes. In: Robertson, G.P., Coleman, D.C., Bledsoe, C.S., Sollins, P. (Eds.), Standard Soil Methods for Long-Term Ecological Research. Oxford University Press, Inc., NY, USA, pp. 143-165.

Hopgood, M.j., Hodson, M.E., Mott, C.J.B., Alloway, B.J., 2003. Effect of soil properties on the ability of EDTA to mobilize lead. In: Seventh International Conference on the Biogeochemistry of Trace Elements. 15-19 June 2003. Uppsala, Sweden, pp. 152-153.

Huang, J.W., Cunningham, S.D., 1996. Lead phytoextraction: species variation in lead uptake and translocation. New Phytol. 134, 75-84.

Huang, J.W., Chen, J., Berti, W.R., Cunningham, S.D., 1997. Phytoremediation of lead-contaminated soils: role of synthetic chelates in lead phytoextraction. Environ. Sci. Technol. 31, 800-805.

Jones, K.C., Peterson, P.J., Davies, B.E., 1984. Extraction of silver from soils and its determination by atomic absorption spectrometry. Geoderma 33, 157-168.

Kabata-Pendias, A., Pendias, H., 2001. Trace Elements in Soils and Plants. CRC Press LLC, Boca Raton, Florida, USA.

Kumar, P.B.A.N., Dushenkov, V., Motto, H., Raskin, I., 1995. Phytoextraction: the use of plants to remove heavy metals from soils. Environ. Sci. Technol. 29, 1232-1238.

Lai, H.Y., Chen, Z.S., 2004. Effects of EDTA on solubility of cadmium, zinc, and lead and their uptake by rainbow pink and vetiver grass. Chemosphere 55, 421-430.

Lindsay, W.L., Norvell, W.A., 1978. Development of a DTPA soil test for zinc, iron, manganese, and copper. Soil Sci. Soc. Am. J. 42, 421-428.

Lombi, E., Wenzel, W.W., Adriano, D.C., 1998. Soil contamination, risk reduction and remediation. Land Contam. Reclam. 6, 183-197.

Lombi, E., Zhao, F.J., Dunham, S.J., McGrath, S.P., 2001. Phytoremediation of heavy metal-contaminated soils: natural hyperaccumulation versus chemically enhanced phytoextraction. J. Environ. Qual. 30, 1919-1926.

Luo, Y.M., Wu, L.H., Jiang, X.J., Wu, S.C., Christie, P., 2000. Chelate-enhanced phytoextraction of metal-contaminated soils and its environmental risk. In: Luo, Y.M., McGrath, S.P., Cao, Z.H., Zhao, F.J., Chen, Y.X., Xu, J.M. (Eds.), Proceeding of 2000 International Conference of Soil Remediation. 15-19 October, 2000. Hangzhou, China.

Mathur, S.P., Levesque, M.P., 1983. The effects of using copper for mitigating histosol subsidence on: 2. the distribution of copper, manganese, zinc, and iron in an organic soil, mineral sublayers, and their mixtures in the context of setting a threshold of phytotoxic soil-copper. Oil Sci. 135, 166-176.

McLean, E.O., 1982. Soil pH and lime requirement. In: Page, A.L. et al. (Eds.), Methods of Soil Analysis. Part 2. Chemical and Microbiological Properties. Second edition. Madison, WI, USA, Agronomy Monograph 9, pp. 199-224.

Mench, M.J., Didier, V.L., Loffler, M., Gomez, A., Masson, P., 1994. A mimicked in-situ remediation study of metalcontaminated soils with emphasis on cadmium and lead. J. Environ. Qual. 23, 58-63.

Miller, W.P., Martens, D.C., Zelazny, L.M., 1986. Effect of sequence in extraction of trace metals from soils. Soil Sci. Soc. Am. J. 50, 598-601.

Nelson, D.W., Sommers, L.E., 1982. Total carbon, organic carbon, and organic matter. In: Page, A.L. et al. (Eds.), Methods of Soil Analysis. Part 2. Chemical and Microbiological Properties. Second edition. Madison, WI, USA, Agronomy Monograph 9, pp. 539-580.

Parkpian, P., Leong, S.T., Laortanakul, P., Phuong, N.T.K., 2002. The benefits and risks of using river sediment for Vietnamese agriculture: a case study of the Nhieu Loc canal in Ho Chi Minh city. J. Environ. Sci. Health. A 37, 10991122.

Puschenreiter, M., Stöger, G., Lombi, E., Horak, O., Wenzel, W.W., 2001. Phytoextraction of heavy metal contaminated soils with Thlaspi goesingense and Amaranthus hybridus: Rhizosphere manipulation using EDTA and ammonium sulfate. J. Plant Nutr. Soil Sci. 164, 615-621.

Rodrigues, S.M., Duarte, A.C., 2003. Phytoremediation: a comparison for developed vs. developing countries. In: seventh International Conference on the Biogeochemistry of Trace Elements. 15-19 June, 2003. Uppsala, Sweden. pp. 116-117.

Salt, D.E., Blaylock, M., Kumar, N.P.B.A., Dushenkov, V., Ensley, B.D., Chet, I., Raskin, I., 1995. Phytoremediation: a novel strategy for the removal of toxic metals from the environment using plants. Biotechnology 13, 468-474.

Sposito, G., Lund, L.J., Chang, A.C., 1982. Trace metal chemistry in arid-zone field soils amended with sewage sludge: fractionation of $\mathrm{Ni}, \mathrm{Cu}, \mathrm{Zn}, \mathrm{Cd}$, and $\mathrm{Pb}$ in solid phases. Soil Sci. Soc. Am. J. 46, 260-264.

Stover, R.C., Sommers, L.E., Silviera, D.J., 1976. Evaluation of metals in wastewater sludge. J. Water Pollut. Control Fed. 48, 2165-2175.

Vig, K., Megharaj, M., Sethunathan, N., Naidu, R., 2003. Bioavailability and toxicity of cadmium to microorganisms and their activities in soil: a review. Adv. Environ. Res. 8, 121-135.

Wenzel, W.W., Lombi, E., Adriano, D.C., 1999. Biogeochemical processes in the rhizosphere: role in phytoremediation of metal-polluted soils. In: Prasad, M.N.V., Hagemeyer, J. (Eds.), Heavy Metal Stress in Plants. Springer, NY, USA, pp. 273-303.

Wu, J., Hsu, F.C., Cunningham, S.D., 1999. Chelate-assisted $\mathrm{Pb}$ phytoremediation: $\mathrm{Pb}$ availability, uptake, and translocation constraints. Environ. Sci. Technol. 33, 1898-1904. 